Copyright (C) 2015 by Academic Publishing House Researcher

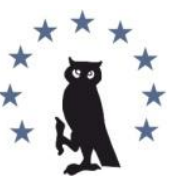

Published in the Russian Federation

European Researcher

Has been issued since 2010.

ISSN 2219-8229

E-ISSN 2224-0136

Vol. 91, Is. 2, pp. 86-93, 2015

DOI: $10.13187 /$ er.2015.91.86

www.erjournal.ru

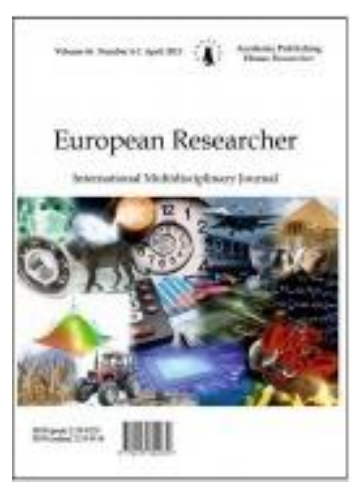

UDC 33

\title{
Impact of Working Capital Management on Firm's Profitability: A Case Study of Cement Industry of Pakistan
}

\author{
${ }^{1}$ Farrukh Shahzad \\ ${ }^{2}$ Zeeshan Fareed \\ 3 Bushra Zulfiqar
}

\author{
${ }^{1}$ Lahore leads University, Lahore, Pakistan \\ MPhil/MS Management Sciences \\ E-mail: farrukh.hailian@gmail.com \\ ${ }^{2}$ COMSATS Institute of Information Technology, Sahiwal, Pakistan \\ MS Scholar \\ E-mail: zeeshanfareed@hotmail.com \\ 3 University of the Punjab, Lahore, Pakistan \\ M.A Economics \\ E-mail: Bushra_zulfiqar786@hotmail.com
}

\section{Abstract}

The fundamental purpose behind this study is to exactly test the effect of working capital management on profitability of cement industry of Pakistan. To explore this relationship between these two, the creator gathered auxiliary information from 12 listed firms in Karachi stock exchange (KSC) for the time period of 2007-2013. For this reason, in this study we utilize variable of return on assets ratio to gauge the benefit of organization and variables of CR, QR, NCA/TA, WCT and ITR as living up to expectations working capital management criteria. The consequences of the research demonstrate that there is a huge effect of the working capital management on profitability of cement industry of Pakistan. Accordingly, manager may improve the Profitability of their organizations by minimizing the inventory turnover ratio, and by diminishing working capital turnover ratio but there is no impact of expanding or diminishing the current proportion on profitability. Along these lines, the results show that through fitting working capital management the organization can expand its benefit. This study shall be helping hand for the cement industry of Pakistan in the management of their working capital in such an effective way thus, to the point that they can increase their profitability.

Keywords: Working capital management; Profitably; Current ratio; Working capital turnover; Inventory turns over.

\section{Introduction}

Ganesan, (2007) in financial issues of organizations, working capital management is a vital component, which has an immediate positive impact on benefit as well as liquidity of the organization. Liquidity and gainfulness are both the two diverse sides of same coin. Ideal level of liquidity ensures a firm to meet their transient obligations and the correct administration of stream 
can be guaranteed by a gainful business. Liquidity demonstrates the capacity of organization in reacting to transient commitments. A firm should streamline its liquidity what's more gainfulness while directing its everyday business operations. Working Capital Management contains extent parity of working capital segments i.e. - debt holders, stock and payables and the utilization of money successfully for day by day business operations. Proper legitimate streamlining of working capital parity means minimizing the working capital prerequisite and acknowledging greatest conceivable revenue.

Ukaegbu, (2014) The target of working capital management is to guarantee that the firm has the capacity reach its working costs furthermore stay in a position to pay fleeting commitments as and when they fall due. The botch of working capital may prompt a liquidity emergency and a diminishment in gainfulness, henceforth influencing the capacity of the firm to keep on working as a going concern.

Muneeb Ahmad Attari, (2012) Working capital has been interesting issue in the field of finance in light of the fact that this single component has significant commitment in adding and decreasing the wealth of shareholders. Monetary system requests a suitable level of harmony between present resources and current liabilities so they are never over contributed nor they are over invested. The discoveries of the examination expresses that better execution of an organization as far as living up to working capital management improve the organization performance. As it were an ideal size of money change cycle can prompt better meeting working capital management lastly demonstrating more prominent effect on organization performance.

Productive management of working Capital is one of the preconditions for the achievement of an endeavor. Effective management of working capital means administration of different parts of working capital in such a route, to the point that a sufficient measure of working capital is kept up for smooth running of a firm and for satisfaction of twin destinations of profitability (Media, 2010)

Working capital Management productivity is key particularly for assembling and development firms, where a real piece of benefits is made out of current resources (Horne, \& Wachowicz, 2000). It straightforwardly influences the productivity and liquidity of firms (Raheman, \& Nasr, 2007). The benefit liquidity tradeoff is vital in light of the fact that if working capital administration is not given due contemplations at that point the organizations are liable to come up short and face chapter 11 (Kargar \& Blumenthal, 1994). The noteworthiness of working capital management effectiveness is undeniable (Filbeck, 2005). Working capital is known as nurturing energy for any financial unit and its administration is considered among the most essential capacity of corporate management. Each association whether, benefit arranged or not, regardless of size and nature of business, obliges essential measure of working capital. Working capital is the most critical component for keeping up liquidity, survival, dissolvability and benefit of business. Working capital management is a standout amongst the most imperative territories while making the liquidity and benefit examinations among firms (Eljelly, 2004), including the choice of the sum and arrangement of current resources and the financing of these benefits. The more noteworthy the relative extent of fluid resources, the lesser the danger of using up money, all different things being measure up to. All individual segments of working capital including money, attractive securities, account receivables and stock administration assume an indispensable part in the performance of any firm.

\section{Cement industries in Pakistan}

The cement manufacturing in Pakistan has arisen a long way since independence when the country had less than half a million tons per annum production capacity. By now it has exceeded 10 million tons per annum as a result of formation of new manufacturing facilities and growth by the existing units. Denationalization and effective price deregulate in 1991-92 heralded a new era in which the industry has reached a level where surplus production after meeting local demand is predictable in 1997.

The cement industry in Pakistan expressions two serious threats: shutting of units based on wet process, and deprived cash flow execution the units incapable of debt overhauling due to swelling cost of electricity, furnace oil and imported craft paper used for cement packing. The cost of furnace oil alone has increased by nearly $100 \%$ in the last 15 months alone. With the increase in furnace oil the increase in electricity tariff has also become inevitable 
At present there are 24 cement industries are operation in Pakistan, 4 of these factories are in public sector and rest are included in private sector. The installed capacity of cement is 16300 thousand tons out of which 9935 thousand tons of cement was produced in 2012-13. The major industry of Pakistan has been allowed duty free import of plant and machinery.

Pakistan has remained a net importer of cement yet because of the privatization of units working under state control and ensuing development programs by the new holders upheld by monetary has pushed the business to a point where the nation is certain to achieve an oversupply circumstance. Be that as it may, the late increment in vitality expense gives chance to the productive units focused around dry methodology to support the circumstances for a moderately more period. It would likewise be conceivable in light of the fact that the extension by the current units and foundation of new units are generally deferred.

Pakistan's concrete business is separated into two different areas, North and South. The northern area includes the Punjab, NWFP, Azad Kashmir and upper parts of Balochistan, though the southern locale involves the whole region of Sindh and lower parts of Balochistan. Generally, the southern district has dependably been surplus in bond generation however with the foundation of more plants in the northern parts of the nation the locale has gotten to be very nearly independent in supply of concrete.

\section{Working capital Concept}

There are two following noteworthy ideas for working capital

- Net working capital

- Gross working capital

Net working capital

Net working capital is the contrast between current assets and current liabilities of an exchange and monetary nature.

\section{Net working capital $($ NWC) $=$ Curret assets - Curret liability}

Gross working capital

The gross working capital is alluded as meeting expectations capital and it incorporate the total current assets of the organizations. On the off chance that the current assets oversee productively by the firm then it give more development and can build the estimation of the firm in the business.

\section{Profitability concept}

According to accounting, profit is the distinction in the middle of value and the expenses of bringing to market whatever it is that is accounted as an endeavor (whether by harvest, extraction, produce, or buy) regarding the part expenses of conveyed products and/or administrations and any working or different costs. Profit is sure gain from a investment or business operation in the wake of subtracting for all costs. The expression benefit fundamentally got from Latin word "profectus" intends to advance. Benefit is characterized in two separate courses, one for bookkeeping and other one for financial aspects, here just accounting definition will be taken.

\section{Problem statement}

The issue articulation to be dissected in this study is:

"Does Working Capital Management influence Profitability of Cement segment of Pakistan?"

\section{Objective of research}

Particular purposes of the study are: business.

- To inspect the proficiency of working capital administration practices of the concrete

- To test how quick the organizations have possessed the capacity to enhance their individual level of productivity in meeting expectations capital administration as for a target level (industry normal).

\section{Literature review}

Numerous studies have contemplated working capital from distinctive perspectives and in diverse situations. The accompanying are exceptionally fascinating and helpful for our examination: 
Smith, \& Begemann, (1997) exceptional that the remarkable objective of working capital Management is striking a harmony in the middle of benefit and liquidity of the firm. The issue emerged on the grounds that the amplification of an association's returns could genuinely undermine its liquidity, and the quest for liquidity tended to weaken returns. This study inspected the relationship in the middle of conventional and option working capital measures and rate of profitability (ROA) as an intermediary for gainfulness, particularly in modern firms recorded on the Johannesburg Stock Exchange (JSE). The issue under scrutiny was to create whether the all the more as of late created option working capital ideas indicated change connected with the degree of profitability to that of customary working capital proportions. Results showed that there were no noteworthy contrasts among the years concerning the autonomous variables. The aftereffects of their stepwise relapse authenticated that aggregate current liabilities partitioned by stores stream represented the vast majority of the variability in ROA. The factual test outcomes demonstrated that a customary working capital influence degree - current liabilities partitioned by trusts stream - showed the best relationship with rate of profitability. Remarkable liquidity ideas, for example, the present and speedy proportions enlisted immaterial affiliations whilst stand out of the more current working capital ideas, the exhaustive liquidity list, demonstrated noteworthy relationship with return on total assets.

Filbeck \& Krueger, (2005) highlighted the essentialness of proficient working capital management by investigating the working capital management strategies of 32 non-financial commercial ventures in the United States (US). As per their discoveries, huge contrasts in living up to expectations capital practices exist among businesses over the long haul. In addition, these working capital practices change essentially inside commercial ventures over the long run. Comparable studies with comparative discoveries were led by Long et al (1993) and Maxwell et al (1998).

Sai Ding (2012) mulled over 116,00o distinctive Chinese firms having diverse proprietorship structure from year 2003 to 2007 and discovered the organizations with high meeting expectations capital are more delicate to interest in living up to expectations money to money streams and low sensitivities of interest in settled funding to money stream.

Sen, (2009) inspected different organizations recorded on Istanbul stock trade to focus relationship between living up to expectations capital administration and ROA (Return on Assets). Specialist discovered essentialness negative relationship between money change cycle, net working capital level, current degree, and debt claims period, stock period and profit for aggregate resources.

Nor Edi Azhar, (2010) inspected 172 recorded organizations arbitrarily from Malaysian stock trade from 2003 to 2007. Scientists dispassionately work to discover a relationship between firms' execution as far as ROA (return on assets), ROE (return on equity) and productivity and working capital administration. Results demonstrated (in the wake of applying measurable strategies) that there is fundamentally negative relationship between firm's execution and working capital variables. Quayyum, (2012) concentrated on assembling division of Bangladesh from 2005 to 2009 with a specific end goal to discover relationship in the middle of gainfulness and working capital management. Scientists found that with the exception of sustenance industry all assembling division has relationship between meeting expectations capital and productivity.

Ghosh, (2003) made an endeavor to analyze the effectiveness of working capital administration of the Indian bond organizations amid 1992 - 1993 to 2001 - 2002. For measuring the effectiveness of working capital management, execution, use and general proficiency records were ascertained as opposed to utilizing some normal working capital administration degrees. Discoveries of the study demonstrated that the Indian Cement Industry all in all did not perform astoundingly well amid this period.

\section{Data collection and Methodology \\ Data collection}

The data utilized for this study is originated from Reviewed Financial Statements of the recorded firms and Balance Sheet Analysis of joint stock companies listed on Karachi Stock Exchange (2007-2013).the organizations utilized are chosen by non-probability sampling method. An aggregate of 12 listed firms are utilized for analysis. Panel data system is tackling since it joins 
time series and cross sectional data. Multiple regressions and estimation is Ordinary Least Squares (OLS) used for analysis of this systematic study.

\title{
Variables
}

Return on Assets (ROA

ROTA utilize as a responding variable. Benefit is measured by Return on Total Assets (ROTA). It is the proportion which measures organization's profit before investment and expenses (PBIT) against its aggregate net resources. The proportion is considered as a marker of how adequately an organization uses its resources for produce income before gathering contractual commitments. The more noteworthy the organization's income in extent to its advantages, the all the more adequately the organization is said to be utilizing its benefits.

\section{Current Ratio (CR)}

CR means to establish the relationship between current assets and current liabilities. Ordinarily, high current ratio is thought to be an indication of money related quality. It is the pointer of the association's capacity to speedily reach its fleeting liabilities

Quick ration (QC)

QC means to create an association between quick or fluid assets and current Liabilities. An advantage is fluid in the event that it can be changed over into money promptly or sensibly soon without a loss of worth. Money is the most fluid resource. It is otherwise called acid test Ratio.

Net Current Assets to Total Assets Ratio (NCA/TA)

It creates the association between current assets and total assets. This ratio furthermore elaborates extend of total resources invest in working capital.

\section{Working capital turnover ratio (WCT)}

Speaks to how successfully working capital is used. Working Capital Turnover Ratio is a relationship between Cost of Sales and net Working Capital.

\section{Inventory turnover ratio (ITR)}

ITR is the quantity of times stock turned over in a year. It is relationship between Cost of Goods Sold and normal stock at expense.

\section{Model specification}

A panel data methodology is utilized for this examination in light of the fact that, as indicated it encourages evacuation of the undetectable heterogeneity that may exist in the diverse firms. Yasser, (2011) inferred that, the first focal point of panel data regression is this that by joining the time series and cross sectional data gives better enlightening data, less co-linearity among the variable and more effectiveness. What's more besides, panel data minimizes the biasness that may be created if separate firm level data are isolated into wide totals. Furthermore at long last, panel data can quantify the impacts that are impractical to see in immaculate cross area or unadulterated time series data.

We used the following economic model for our study.

$$
\boldsymbol{R O A}=\boldsymbol{\beta}_{0}+\beta_{1} \boldsymbol{C R}+\beta_{2} Q \boldsymbol{C}+\beta_{3} \boldsymbol{N C A} \backslash \boldsymbol{T A}+\beta_{4} \boldsymbol{W C T}+\beta_{5} I T R+\boldsymbol{\mu}
$$

$\beta_{0}, \beta_{1}, \beta_{2}, \beta_{3}, \beta_{4}$ and $\beta_{5}$ are represent the coefficient of each variable or parameter of the regression. $\mu$ indicate the error term. Following are variables that used to build the study

\author{
Where, \\ ROA = Return on Assets \\ $\mathrm{CR}=$ Current Ratio \\ $\mathrm{QC}=$ Quick Ratio \\ NCA/TA $=$ Net Current Assets over Total Assets \\ WCT $=$ Working Capital Turnover Ratio \\ ITR= Inventory Turnover Ratio \\ $\mu=$ Error Term
}


Descriptive Statistics

Table 1. Descriptive

\begin{tabular}{|c|c|c|}
\hline Variable & Mean & Std. Deviation \\
\hline ROA & 7.232 & 13.43284 \\
\hline CR & 104.0300 & 67.26479 \\
\hline QR & 91.0400 & 67.951423 \\
\hline NCA/TA & .38595 & .148521 \\
\hline WCT & 3.65971 & 39.95876 \\
\hline ITR & 36.98562 & 65.45896 \\
\hline
\end{tabular}

Empirical result of multiple regressions

Table 2. Regression result

\begin{tabular}{|c|c|c|c|c|}
\hline \multicolumn{5}{|c|}{ Dependent Variable: ROA } \\
\hline \multicolumn{5}{|c|}{ Method: Least Squares } \\
\hline \multicolumn{5}{|c|}{ Date: 11/o1/15 Time: 19:42 } \\
\hline \multicolumn{5}{|c|}{ Sample: 20072013} \\
\hline \multicolumn{5}{|c|}{ Included observations: 84} \\
\hline Variables & Coefficient & Std. Error & t-Statistic & Prob. \\
\hline $\mathbf{C}$ & 2.22187992 & 0.9854 & 2.2548 & 0.0132 \\
\hline CR & 4.22056248 & 1.2356 & 3.4158 & 0.0091 \\
\hline $\mathbf{Q R}$ & -7.50149412 & 2.2548 & -3.3269 & 0.0002 \\
\hline NCA/TA & 0.31353192 & .1548 & 2.0254 & 0.0012 \\
\hline WCT & -1.99017717 & 2.0211 & -.9847 & 0.5231 \\
\hline ITR & 2.865941 & 2.0254 & 1.415 & 0.2351 \\
\hline \multicolumn{2}{|c|}{ R Square $=0.54$} & \multicolumn{3}{|c|}{ Mean dependent var $=7.23207$} \\
\hline \multicolumn{2}{|c|}{ Adjusted R2 $=0.49$} & \multicolumn{3}{|c|}{ S.D. dependent var $=13.43284$} \\
\hline \multicolumn{2}{|c|}{ F-statistic $=6.853968$} & \multicolumn{3}{|c|}{ Sum squared resid = 109.1990} \\
\hline \multicolumn{2}{|c|}{ Prob (F-statistic) = 0.008695} & \multicolumn{3}{|c|}{ Durbin-Watson = 1.1236} \\
\hline
\end{tabular}

\section{Analysis and Findings}

Analyze the relationship between dependent and independent variables by multiple regression models that mentioned earlier. Descriptive statistics and regression results are given respectively on Table 1 and Table 2 . The proposed model careful results are outlined by the above table. The slope coefficients of the CR, NCA/TA and ITR in the OLS researches have positive effect on ROA though the incline coefficients of the QR and WCT have negative effect on ROA.

The Adjusted $\mathrm{R}$ square is .49 which clarifies $49 \%$ assortment in the dependent variable (ROA) spoke to by the illustrative variables CR, QR, NCA/TA, WCT and ITR. The estimation of Durbin Watson is 1.1236 which suggests that there is certain autocorrelation of remaining.

The change of one percent (\%) in CR achieves $4.22 \%$ change in ROA while QR, NCA/TA, WCT and ITR will realize -7.50 \%, .31 \%, -1.99\%, $2.86 \%$ changed by 1 percent change in ROA respectively by considers other variable consistent. Evaluation of CR, NCA/TA and QR are highly significant. WCT and ITR reveal the insignificant relation with the ROA.

\section{Conclusion and implication}

In money related administration, you can about capital administration studies are not as mainstream as those identified with capital structure and capital planning. Of in this viewpoint, this study plans to investigate the determinants of firm gainfulness of variables connected with the administration of working capital with a specimen of steam for bonds organizations the period 2007-2013. 
Results recommend that the benefit of the endeavor may be expanded by shortening of stock periods. The positive relationship between records receivable period and gainfulness can be diminished because of what clients need of a chance time to assess the nature of items that buy organizations with gainful. Nevertheless, this exact conclusion clashes with some budgetary models that clarify the business credit. Exchange receivables are for the most part less expensive (Emery, 1984b) debatable fleeting speculations, it is sensible that, most importantly, business high benefit that are most fluid exchange moderately a lot of business credit to their purchasers. Since, as indicated by the hypothesis of liquidity, fluids are less inclined to business credit application and more prone to offer. An alternate observational conclusion is comparable, the negative relationship in the middle of period and stock benefit and this may be the aftereffect of weight on pioneers in deals incomes to a level beneath and more stock, as examined in studio. Lever is an alternate variable that influence productivity adversely stops. This conclusion can be clarified recommendations that contending organizations are firmly prepared sweeter that will restrain venture. Accordingly their energy lacking rivalry can prompt a diminishing in benefit. The one of a kind variables in the model studio has a fundamentally positive impact on gainfulness is the development of the organization (available to be purchased). On account of an organization can get a few points of interest like restraining infrastructure or dealing force in view of development as an impression of economies of scale, a positive relationship in the middle of development and expected productivity. Results clearly have shown that my managing the working capital accordingly and efficiently will be positive effect on the productivity of the cement industry of the Pakistan.

\section{References:}

1. Eljelly, A. (2004). Liquidity-profitability tradeoff: An empirical investigation in an emerging market. International Journal of Commerce and Management, 14(2), 48-61.

2. Filbeck, G. \&. (2005). An analysis of working capital management results across industries. Mid-American Journal of Business, 2O(2), 11-18.

3. Filbeck, G., \& Krueger, T. (2005). Industry related differences in working capital management. Mid-American Journal of Business, 2O(2), 11-18.

4. Ganesan, V. (2007). An Analysis of Working Capital Management Efficiency in Telecommunication Equipment Industry". Rivier Academic journal, 3(2), 13.

5. Ghosh, D. S. (2003). Working capital management efficiency : A study on the Indian cement industry. The Institute of Cost and Works Accountants of India, 12.

6. Horne, J., \& Wachowicz, J. (2000). Fundamentals of Financial Management. New york, NY: Prentice Hall Publishers.

7. Kargar, J., \& Blumenthal, R. (1994). Leverage impact of working capital in small businesses. TMA Journal, 14(6), 46-53.

8. Long, M., Malitz, I., \& Ravid, S. (1993). Trade credit, quality guarantees, and product marketability. Financial Management, 22(4), 117-127.

9. Maxwell, C., Gitman, L., \& Smith, S. (1998). Working capital management and financialservice consumption preferences of US and foreign firms: a comparison of 1979 and 1996 preferences. Financial Practice and Education, 8(2), 46-52.

10. Media., B. L. (2010). F9 Financial Management. London, UK: SBS Publications.

11. Muneeb Ahmad Attari, K. R. (2012). The Optimal Relationship of Cash Conversion Cycle with Firm size and profitability. International Journal of Academic Research in Business and Social scinences., 15(3).

12. Nor Edi Azhar, S. H. (2010). Working Capital Management: The Effect of Market Valuation and Profitability in Malaysia. International Journal of Business and Management., 14(1).

13. Quayyum, S. T. (2012). Relationship between Working Capital Management and Profitability in Context of Manufacturing Industries in Bangladesh. International Journal of Business and Management.

14. Raheman, A., \& Nasr, M. (2007). Working capital management and profitability case of Pakistan firms. International Review of Business Research Papers, 3(1), 279-300.

15. Sai Ding a, A. G. (2012). Investment and financing constraints in China: Does working capital management make a difference. Journal of Banking \& Finance, 15(1), 125-136. 
16. Sen, M. (2009). Relationship between Efficiency Level of Working Capital Management and Return on Total Assets in Ise. international journal of Business \& finance., 11(2).

17. Smith, M., \& Begemann, E. (1997). Measuring association between working capital and return on investment. South African. Journal of Business Management, 28(1), 28.

18. Ukaegbu, B. (2014). The significance of working capital management in determining firm profitability: Evidence from developing economies in Africa. ScienceDirect Research in International Business and Finance, 31(1), 1-16.

19. Yasser. (2011). Corporate governnance and performance: evidence from listed companies. International reserch journal of library information, 2, 245-263. 